\title{
Denomination composition of trade and trade balance: evidence from Turkey
}

\section{Hakan Berument \& Nergiz Dincer}

To cite this article: Hakan Berument \& Nergiz Dincer (2005) Denomination composition of trade and trade balance: evidence from Turkey, Applied Economics, 37:10, 1177-1191, DOI: $10.1080 / 00036840500109159$

To link to this article: http://dx.doi.org/10.1080/00036840500109159

曲 Published online: 16 Aug 2006.

Submit your article to this journal $\pi$

Џll Article views: 85

Q View related articles $\sqsubset$

4 Citing articles: 13 View citing articles 준 


\title{
Denomination composition of trade and trade balance: evidence from Turkey
}

\author{
Hakan Berument ${ }^{\mathrm{a}, *}$ and Nergiz Dincer ${ }^{\mathrm{b}}$ \\ ${ }^{a}$ Department of Economics, Bilkent University, 06800 Ankara, Turkey \\ ${ }^{\mathrm{b}}$ State Planning Organization, Necatibey cad. No:108, Room:1016, 06100 \\ Ankara, Turkey
}

The currency denominations of a country's exports and imports are not necessarily the same. If this is the case, then a change in the exchange rate parity among major currencies will affect the trade balance. The empirical evidence provided from Turkey - where exports are mostly denominated in Euros and imports are mostly denominated in USD - suggests that an appreciation of the Euro against the USD would increase the output in the long-run, appreciate the local currency and improve the trade balance for the 1985:01 2003:07 period.

\section{Introduction}

Over the last two decades, Turkey has experienced two detrimental crises, in 1994 and 2001. Both these crises were triggered by changes in the trade deficit. In the pre-1994 period, there was not a big problem in the balance of payments in Turkey. However, with the structural problems that started to influence the macroeconomic balances in 1993, Turkey became vulnerable to the magnitude of the trade imbalances. The trade balance to the GNP ratio fluctuated around $-5 \%$, until 1993 when the trade deficit increased to above $10 \%$, as seen in Fig. 1. After 1995, Turkey financed its large public deficits with private savings. Whenever private savings were not enough to finance the high fiscal deficits, Turkey financed them with the capital account, which ultimately caused the trade deficit. In the 1995-1999 period, the trade balance-GDP ratio was around $-10 \%$; however just before the 2001 economic crisis, this ratio increased to an unsustainable $-20 \%$, and the crisis occurred on 22 February 2001. Thus, low trade deficits are vital for the stability of the economy, and it is necessary to examine the shocks that would affect the trade balance. The conjecture in the present study is that one of the external but important determinants of a variable - USD-Euro parity - affects the trade balance for Turkey. The findings support the view that change in the USD-Euro parity improves the trade balance while increasing the relative input and appreciating the real exchange rate.

Before analysing the effects of USD-Euro parity on the trade balance, it is necessary to determine the links between USD-Euro parity and the trade balance for the Turkish economy. Turkey, a small open economy, is a member of the European Customs Union with no restrictions on the trade of most goods. About half of the country's exports are to European Union countries and $49.3 \%$ of exports is in Euros, whereas $42.7 \%$ of all exports is in USD. However, only $38.7 \%$ of all imports is in Euros and $56 \%$ is in US dollars. ${ }^{1}$ To sum up, the denomination composition of exports and imports is not symmetric

\footnotetext{
*Corresponding author. E-mail: berument@bilkent.edu.tr
} 


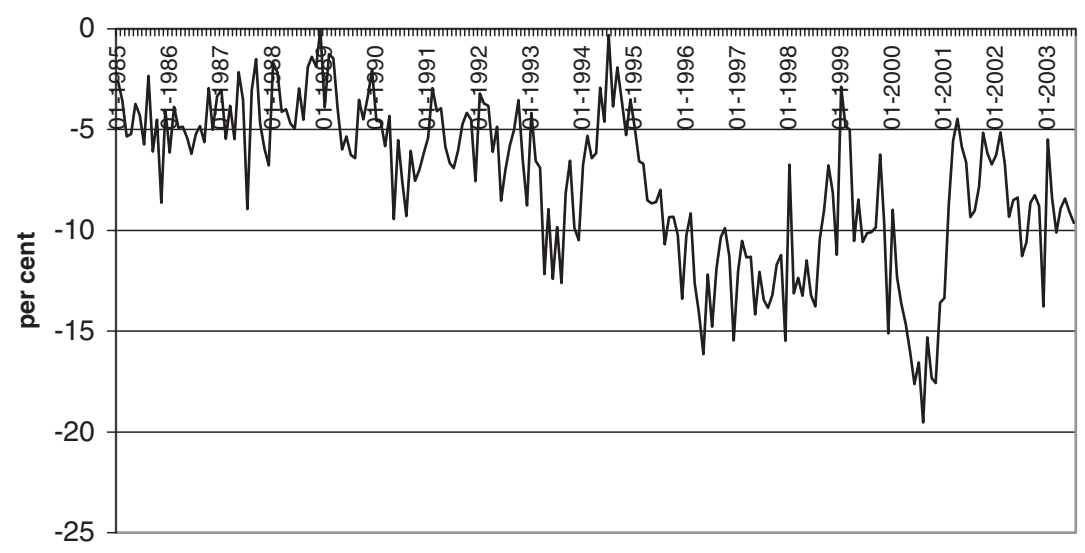

Fig. 1. The ratio of trade balance to GNP

in Turkey. Exports are mostly denominated in Euros whereas imports are mostly denominated in USD. Therefore, a change in USD-Euro parity has asymmetric effects on imports and exports in Turkey, meaning an influential effect on trade balance, which makes it interesting to examine Turkey's case. As an example, in 2003 USD-Euro parity significantly increased and Turkey experienced an unexpected increase in its exports. Calculations show that the gain in exports arising from the increase in parity is 12 percentage points, which is a significant contribution.

Furthermore, Turkey's imported intermediate and raw materials, which constitute around $73 \%$ of total imports, are mostly USD dominated. Thus, as USD-Euro parity increases (appreciation of Euro against USD), lower input prices compared to export goods prices is the result. In other words, with a rise in USD-Euro parity, export prices increase in real terms compared to imports prices; thus, the terms of trade improve. Therefore, one may interpret a shock to parity as a shock to the terms of trade.

This study considers USD-Euro parity as one of the determinants of Turkish trade and looks at the direct effect of USD-Euro parity changes on the trade balance and real exchange rate. To the best of knowledge, there are no studies examining the effects of a change in parity of major currencies on a developing country's economic performance, which is the aim of this paper. However, there are studies examining the effects of nominal shocks on the trade balance. Fisher and Huh (2002) studied the relationship between nominal shocks, the real exchange rate and trade balances using a structural VAR model framework, allowing nominal shocks to have long-run effects on the real exchange rate and the trade balance.

Even if there is no literature on the effect of USD-Euro parity on the economies of developing countries, one may observe the effects of this change through the terms of trade. There is extensive literature concerning the effects of an exogeneous change in a country's terms of trade on the trade balance of a country. Harberger (1950) and Laursen and Metzler (1959) are the influential studies in this area. They suggest that an increase in the terms of trade of a small open economy would result in an improvement in the country's trade balance, which is called the Harberger-Laursen-Metzler (HLM) effect. The idea behind their results is that an improvement in the terms of trade increases a country's real income. With the Keynesian consumption function they use, the marginal propensity to consume is less than one, resulting in an increase in private savings and therefore an improvement in the trade balance. Backus (1993) and Mendoza (1992) analysed the subject using perfect foresight models. These studies argued that the relationship between the trade balance and the terms of trade depends on the persistence of terms of trade fluctuations and the link between the rate of time preference and future utility. There are other theoretical studies analysing the HLM effect in different frameworks: Sachs (1981), Obsfeld (1982) and Mendoza (1995).

Econometric studies on this subject are not extensive. Backus et al. (1994) describe the positive

\footnotetext{
${ }^{1}$ The denomination composition figures for exports and imports are taken from the Balance of Payments Report of the Central Bank of Turkey and covers the January-October 2003 period.
} 


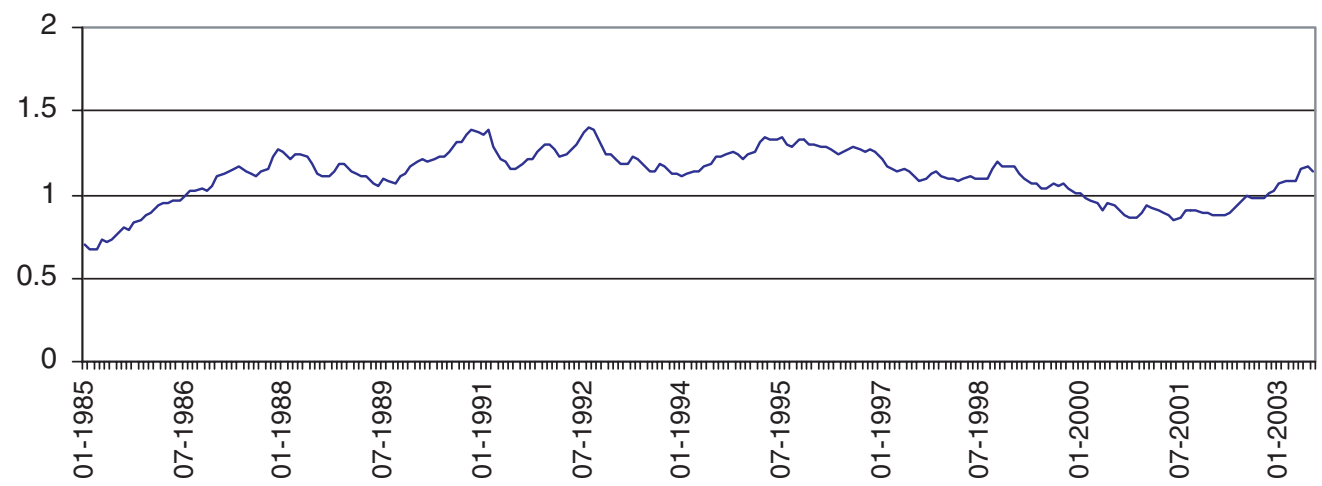

Fig. 2. USD-Euro parity

correlation between the terms of trade and the trade balance across industrialized countries. Mendoza (1995) analyses the effects of terms of trade on real income and the trade balance using impulse response functions. His evidence suggests that an improvement in terms of trade results in an increase in real income and an improvement in the trade balance for G-7 countries. Using panel data, Kent (1997) argues that countries with the least persistent terms of trade shocks exhibit a positive relationship between these shocks and the current account, whereas countries with the most persistent terms of trade shocks exhibit a negative relationship. Finally, Cashin and McDermott (1998) support the HLM effect by using the substitution effect argument for the OECD countries.

Although there is extensive literature analysing the effects of an exogenous improvement in the terms of trade on the trade balance, it is also important to note that USD-Euro parity is one of the important determinants of terms of trade, therefore the direct effect of change in parity on the trade balance also constitutes importance. Terms of trade can also be affected by other major countries' value, productivity differences and changes in the demands of export and import products. This study looks only at the effects of USD-Euro parity changes on economic performance. ${ }^{2}$

In order to explore the dynamic effects of the change in the USD-Euro parity on the Turkish economy, VAR methodology was used. Considering the fact that Turkey is a small-open economy, the change in USD-Euro parity would affect the economic performance of Turkey. However, the reverse, that Turkish economic indicators would have an effect on world prices, is not realistic. Therefore, following
Cushman and Zha (1997), an identified VAR model with block exogeneity is used, which allows the identification of foreign shocks from the point of the view of the small open economy.

The results of the impulse response functions that are performed with the identified VAR model with the block exogeneity method suggest that a positive shock to USD-Euro parity appreciates the local currency, improves the Turkish trade balance for eight months, and increases Turkish output relative to other industrial countries' industrial production after a year.

The next section briefly discusses the development in USD-Euro parity. Section III presents the data and descriptive statistics. Section IV discusses the methodology, which is identified VAR model with block exogeneity. In Section V, the estimates and the results are presented. Finally, Section VI concludes.

\section{Developments in USD-Euro Parity}

It is necessary to analyse the movements in the parity before exploring its effects on the economy. Over the last two decades, USD-Euro parity has followed a fluctuating pattern, as seen in Fig. 2. At the beginning of the sample, January 1985, the USD was more valuable than the Euro, when the Euro was a representative currency called the Ecu. However, from 1986 onwards the trend changed and USD-Euro parity increased. This trend continued until 2000. On 1 January 1999, the currencies of the member states of the Euro-Zone were locked together under the Euro. From that date until 1 January 2002, the Euro was the currency of the participating member states while the national currency units

\footnotetext{
${ }^{2}$ The later stages of the paper also provided a set of analyses that take into consideration the terms of trade changes.
} 
were sub-divisions of the Euro. Since, the 1 January 1999, the Euro may be regarded as a currency in its own right. Governments, banks and many large companies started to invoice and account in Euros. In other words, between 2000 and 2002 the Euro-area was in a transition period. During this transition period, USD-Euro parity was less than 1, implying a stronger USD. However, from November 2002 to July 2003, which is the end of the sample considered in this study, the structure changed and the USD-Euro parity exhibited an increasing trend.

To sum up, the Euro, which was only a representative currency until 1999, followed a volatile path against the USD in the last decade and nowadays is on the way to becoming a vehicle currency in the world. It is the aim of the finance market to predict the future path of the parity; however, it is not easy to decrease the error-bands in the parity forecasts. Therefore, it is important to distinguish the stochastic pattern of the trade balance, which is affected by the change in parity. It would not be possible to achieve the desired macroeconomic balances without considering the effects of a possible change in the parity.

\section{Data and Descriptive Statistics}

The data set used in the study is monthly and covers the period 1985:01 to 2003:07. Data in the model is as follows: USD-Euro parity, parity, the value of the Euro against the USD. However, before December 1998 the value of the ECU against the USD was taken as the parity, and this data is obtained from the European Central Bank web site (www.ecb.int). For the real exchange rate, two definitions are used. First, the real exchange rate is calculated as the USD times the US CPI divided by the wholesale price index of Turkey, rer $_{t}$ (an increase in the real exchange rate means a depreciation; this is the most widely taken real exchange rate definition for economists). Second, the State Planning Organization official definition of real exchange rate, rerspo ${ }_{t}$, is calculated with relative weights of 0.75 USD and 0.25 Euro and the corresponding countries' prices and taken from the Main Economic Indicators of State Planning Organization (SPO). The price index and the nominal exchange rate indicator (USD values) are obtained from the Central Bank of the Republic of Turkey data delivery system (http://tcmbf40.tcmb.gov.tr/ cbt.html), and the US CPI is from the web site of St Louis FED (http://research.stlouisfed.org/fred2). Relative output, rely $y_{t}$, is the ratio of domestic industrial production, from the Central Bank's web site, to the industrial countries seasonally adjusted industrial production, which is obtained from the IMF-IFS tape.
Finally, trade balance, $\operatorname{trb}_{t}$, is the ratio of the difference between exports minus imports in TL to nominal industrial production (generated by the industrial production index and the wholesale price index), where export and import series are from the Main Economic Indicators of State Planning Organization. These are $f o b$ values in million dollars. All the series enter into the analysis in their logarithmic form except trade balance and relative income, which are entered as ratios.

The first column of Table 1 summarizes the results obtained from testing parity, real exchange rate, relative income and trade deficit for a unit root with the Augmented Dickey-Fuller (ADF) test with constants. In the second column, the ADF test is repeated for the first differences of the data. In the first column, one cannot reject the null hypothesis of no unit root in the level of each series. However, one can reject the null of no unit root in the first difference of each series. Thus, the ADF tests suggest that parity, real exchange rate, relative income and trade deficit are $I(1)$.

Table 2 gives the correlation matrix of the first differences of parity, real exchange rate, relative income and trade balance (their first differences are included as the levels are not stationary). The results suggest that parity is positively correlated with relative output and trade balance but negatively correlated with the real exchange rate. Thus, an appreciation of USD-Euro parity increases the relative income, improves the trade balance and appreciates the real exchange rate.

Table 1. Unit root tests

\begin{tabular}{lll}
\hline Variables & Level & First difference \\
\hline Parity & -2.52 & $-3.69 * * *$ \\
Real exchange rate & -2.15 & $-4.40 * * *$ \\
Relative income & -1.78 & $-4.60 * * *$ \\
Trade balance & -2.29 & $-4.61 * * *$ \\
\hline
\end{tabular}

$\left(^{+}\right)$The critical value is -2.88 .

*** indicate the level of significance at the $1 \%$ level.

Table 2. Correlation matrix

\begin{tabular}{lrcrr}
\hline & Parity & $\begin{array}{l}\text { Relative } \\
\text { income }\end{array}$ & $\begin{array}{l}\text { Real } \\
\text { exchange } \\
\text { rate }\end{array}$ & $\begin{array}{l}\text { Trade } \\
\text { balance }\end{array}$ \\
\hline Parity & 1.00 & 0.04 & -0.29 & 0.10 \\
$\begin{array}{l}\text { Relative income } \\
\begin{array}{l}\text { Real exchange } \\
\text { rate }\end{array}\end{array}$ & -0.04 & 1.00 & -0.03 & -0.09 \\
$\begin{array}{l}\text { Trade balance } \\
\text { Trade ba }\end{array}$ & 0.10 & -0.03 & 1.00 & -0.04 \\
\hline
\end{tabular}


Table 3. Cross correlations of parity with other variables

\begin{tabular}{ccll}
\hline Lags & $\begin{array}{l}\text { Relative } \\
\text { income }\end{array}$ & $\begin{array}{l}\text { Real } \\
\text { exchange rate }\end{array}$ & $\begin{array}{l}\text { Trade } \\
\text { balance }\end{array}$ \\
\hline 0 & 0.22 & -0.65 & 0.06 \\
1 & 0.20 & -0.63 & 0.07 \\
2 & 0.18 & -0.61 & 0.09 \\
3 & 0.15 & -0.59 & 0.12 \\
4 & 0.11 & -0.57 & 0.13 \\
5 & 0.07 & -0.55 & 0.15 \\
6 & 0.04 & -0.54 & 0.18 \\
7 & 0.02 & -0.52 & 0.21 \\
8 & -0.01 & -0.51 & 0.24 \\
9 & -0.03 & -0.49 & 0.26 \\
10 & -0.05 & -0.46 & 0.27 \\
11 & -0.06 & -0.44 & 0.29 \\
12 & -0.08 & -0.41 & 0.31 \\
\hline
\end{tabular}

Table 4. Co-integration test

\begin{tabular}{|c|c|c|c|c|}
\hline $\begin{array}{l}\text { Null } \\
\text { hypothesis }\end{array}$ & $\begin{array}{l}\text { Alternative } \\
\text { hypothesis }\end{array}$ & & $\begin{array}{l}95 \% \\
\text { critical } \\
\text { value }\end{array}$ & $\begin{array}{l}99 \% \\
\text { critical } \\
\text { value }\end{array}$ \\
\hline$\lambda_{\text {trace }}$ tests & & $\lambda_{\text {trace }}$ value & & \\
\hline$R=0$ & $r>0$ & 46.81 & 35.07 & 40.20 \\
\hline$R \leq \lambda 1$ & $r>1$ & 21.17 & 20.17 & 24.99 \\
\hline$r \leq 2$ & $r>2$ & 4.61 & 9.10 & 12.74 \\
\hline$\lambda_{\max }$ tests & & $\lambda_{\max }$ value & & \\
\hline$r=0$ & $r=1$ & 25.64 & 21.89 & 26.41 \\
\hline$r=1$ & $r=2$ & 16.56 & 15.75 & 19.83 \\
\hline$r=2$ & $r=3$ & 4.61 & 9.10 & 12.74 \\
\hline
\end{tabular}

Table 3 reports the cross-correlations of USD-Euro parity with the real exchange rate, relative income and trade balance at various leads. The lead number indicates the number of months by which the variables are led relative to parity. Table 4 suggests that USD-Euro parity is positively correlated with relative income for up to 7 months. The negative correlation of parity with the real exchange rate depreciation is valid for the whole period. The positive correlation of parity with trade balance continues for all the leads. Therefore, cross correlation results support the results of the correlation matrix. There is a positive static relationship between parity relative income and trade balance; however, the relationship between parity and real exchange rate depreciation is negative.

Table 4 reports the Johansen co-integration test performed with relative income, real exchange rate and trade deficit; where parity is taken as exogenous, considering that it is unaffected by the Turkish economy. Under the Johansen $\lambda_{\text {trace }}$ test, the null hypothesis that there is less than one or exactly one co-integrating vector is rejected at the $5 \%$ significance level, however one cannot reject there is less than two or exactly two co-integrating vectors at the 5\% significance level. Under the Johansen $\lambda_{\max }$ test, the null hypothesis that there is one but not two co-integrating vectors is rejected but one cannot reject there are two but not three co-integrating vectors hypothesis. Therefore, there is a long run relationship between parity, relative income, real exchange rate and trade balance; in other words, they are co-integrated as shown in Table 4. Thus, following Sims et al. (1999), one enters these variables into the system in levels when the VAR analysis is performed.

This section reports the existence of static and dynamic correlation between USD-Euro parity and relative income, real exchange rate and trade balance, respectively. However, these correlations are pairwise and do not account for the interrelationships among themselves. Thus, in the next section, a VAR model that accounts for the inner relationships is estimated. Furthermore, VAR models capture dynamic relationships and control for other variables. Lastly, the existence of a long-run relationship among the variables of interest encourages us to use these variables in their log levels.

\section{Model Specification (VAR)}

The aim of this paper is to assess the dynamic effects of a change in USD-Euro parity on the Turkish economy. In order to capture the responses of domestic variables to a foreign shock, impulse response functions using a VAR would be one method for assessing the dynamic effects. However, there is a serious drawback of this method when it is used in its standard form, as in Sims (1972). That is, the foreign variables are affected by the domestic variables with lags, which is not the case for a small open economy, whereas the present study wants to identify the shocks from the perspective of a small open economy, Turkey. Therefore, for the present purpose, the impact of foreign shock on the domestic economy is important, not vice versa.

The identified VAR model with block exogeneity, however, overcomes this problem and has another advantage. With this method, one may specify economically meaningful simultaneous interactions among variables, instead of a complete set of equations. In other words, there is a restriction on lagged relationships; they are determined by the data.

To figure out the details of the identified VAR model with block exogeneity, one may start with a general specification as in Zha (1999).

$$
A(L) y(t)=\varepsilon(t)
$$


In Equation $1 y(t)$ is an $m \times 1$ vector of observations, $A(L)$ is an $m \times m$ matrix polynomial in the lag operator $L$ with non-negative powers and $\varepsilon(t)$ is an $m \times 1$ vector of structural disturbances. The specification in matrix form is as follows:

$$
\begin{aligned}
& y(t)=\left[\begin{array}{l}
y_{1}(t) \\
y_{2}(t)
\end{array}\right], \quad A(L)=\left[\begin{array}{cc}
A_{11}(L) & 0 \\
A_{21}(L) & A_{22}(L)
\end{array}\right], \\
& \varepsilon(t)=\left[\begin{array}{l}
\varepsilon_{1}(t) \\
\varepsilon_{2}(t)
\end{array}\right] .
\end{aligned}
$$

The assumptions of Equation 2 are that the coefficient matrix of $L^{0} A_{0}$, is non-singular and $\varepsilon(t)$ is uncorrelated with past $y(t-s)$ for $s>0$. In the $A$ (L) matrix, $A_{12}(L)$ is zero representing the block exogeneity and it means that the first block $y_{1}(t)$ is exogeneous to the second block $y_{1}(t)$ both contemporaneously and for lagged values of the variables.

The maximum likelihood estimation of VAR models (Sims, 1986; Gordon and Leeper, 1994) is not applicable to the identified VAR model with block exogeneity. Therefore, the maximum likelihood estimation and inference for the second block are computed with the conventional Choleski normalization with the modified error bands of Sims and Zha (1998). The detailed methodology can be followed up from Zha (1999).

The lag order of the identified VAR model with block exogeneity is 1 , as the Schwartz Criteria test suggests, and it is set up for Turkey as $y_{1}=$ [USD-Euro parity $]$ and $y_{2}=$ [real exchange rate, relative output, trade balance]'. Therefore, the foreign shock that one is trying to find the impact of changes the USD-Euro parity in the analysis. With this specification, the parity is not subject to any feedback from the domestic economy, neither contemporaneously nor with lags. However, the reverse is valid; that is, domestic economy is affected by the foreign shock both contemporaneously and with lags. On $y_{2}$, the ordering of variables is important. It is assumed that the relative income will contemporaneously affect the real exchange rate and trade balance, but the relative income will not be contemporaneously affected by these two. The real exchange rate will contemporaneously affect the trade balance but is not affected by relative income. Moreover, the trade balance will be contemporaneously affected by relative income and real exchange rate, but not contemporaneously affect other variables. Here, two things are important: (1) all three variables affect each other with lags and (2) USD-Euro parity will affect these three variables both contemporaneously and with lags but will not be affected by these three in any way. In the specification, we also add a constant term and monthly dummies to account for seasonality.

\section{Impulse Response Functions}

The effects of a positive shock to USD-Euro parity (USD value of Euro) are assessed by using impulse response function analysis. Figures 3 and 4 report the impulse response functions of the relative income, real exchange rate and trade balance when one standard deviation shock is given to the parity with two different real exchange rate definitions. Following Sims and Zha (1998), the $90 \%$ confidence bands are calculated using the bootstrap method with 500 draws, and the middle line represents the median of the draws.

Figure 3 reports impulse response functions of parity, parity $_{t}$, on relative income, rely, real exchange rate calculated with dollar, rer $_{t}$, and trade balance, $t b_{t}$. In the first diagram, a positive shock to USDEuro parity is presented. The second diagram shows that except for the first month a positive shock to USD-Euro parity does not affect the relative income in a statistically significant fashion for 14 months. Then, relative income increases for three months and after the 16th month the effect of a positive shock of parity on relative income disappears in a statistically significant fashion. The third diagram shows the response of the real exchange rate to a positive shock to parity. The real exchange rate appreciates for the whole period as a response to a shock to parity and this effect is statistically significant. In the fourth diagram, the effect of a positive shock to USD-Euro parity on the trade balance is presented. Trade balance improves for six months in a statistically significant fashion. The initial effect of the positive shock to parity on the trade balance is small, but the effect of the shock shows an increasing trend in the first four months. The peak point of the increase on the trade balance is at the fourth month. However, after the fourth month, the effect starts to decrease; after the seventh month, the effect is no longer statistically significant. Therefore, Fig. 3 indicates that the appreciation of USD-Euro parity results in an appreciation of the real exchange rate of Turkey, an increase in the relative income and an improvement in the trade balance. Therefore, the Turkish economy benefits from the appreciation of USD-Euro parity.

Figure 4 repeats the analysis of Fig. 3, but uses the official SPO definition of the real exchange rate rather than the most widely used one. The results are similar, but there are quantitative differences. The first diagram, as before, presents a positive shock to 
i. Response of parity to parity

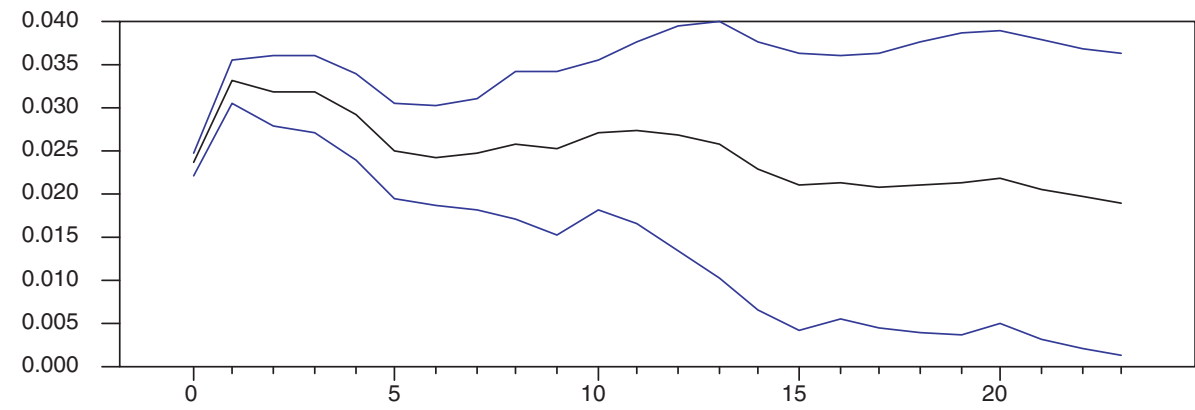

ii. Response of rely to parity

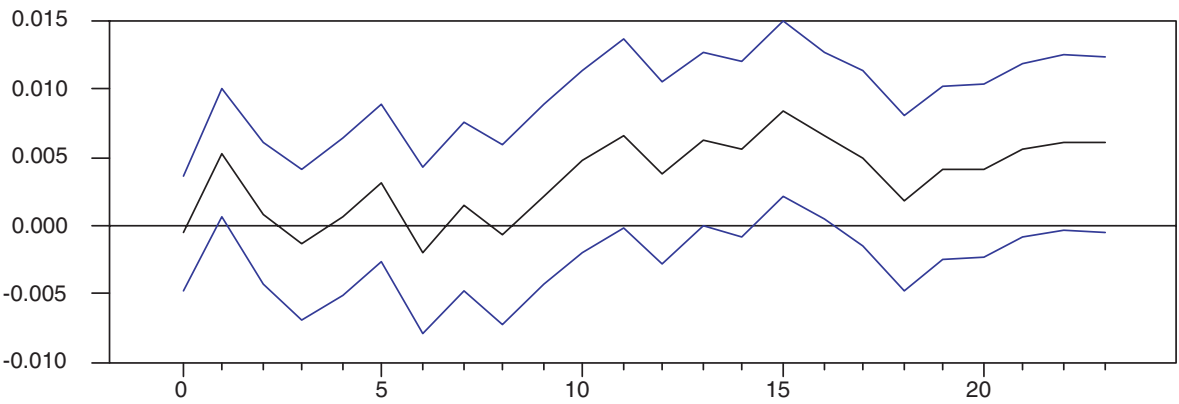

iii. Response of rer $_{t}$ to parity

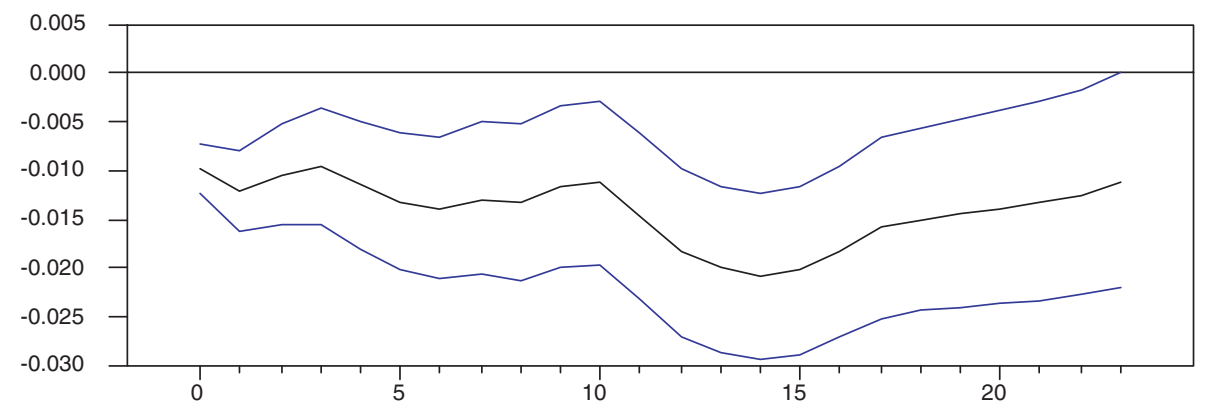

iv. Response of $t r b_{t}$ to parity $y_{t}$

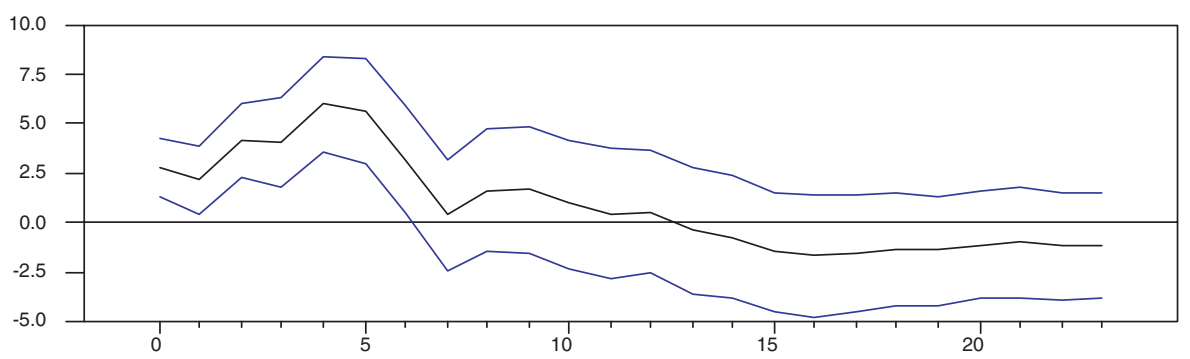

Fig. 3. Impulse response functions

USD-Euro parity. In the second diagram, it is seen that a positive shock to USD-Euro parity does not affect the relative income in a statistically significant fashion until the 14th month. Between the 14th and 16th months, relative income increases. Then, the effect of the shock dies out. The third diagram shows the response of the real exchange rate to a positive shock to parity. The response of the real 
i. Response of parity to parity

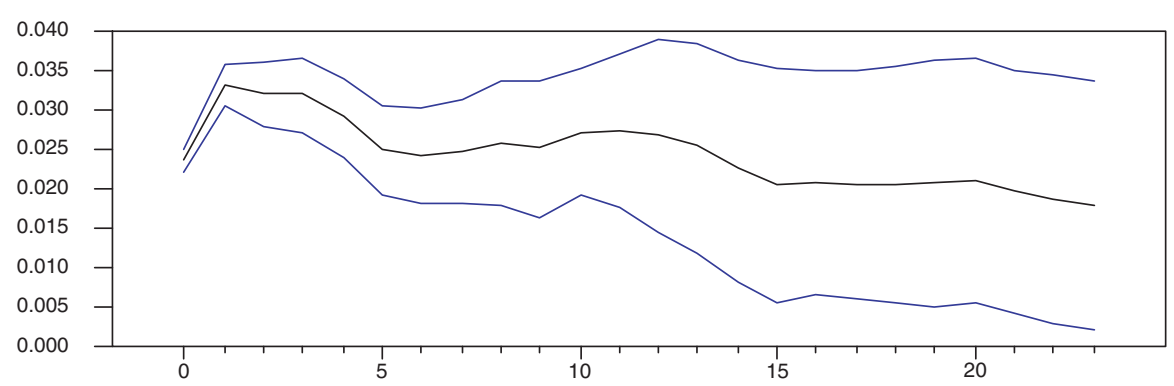

ii. Response of rely to parity

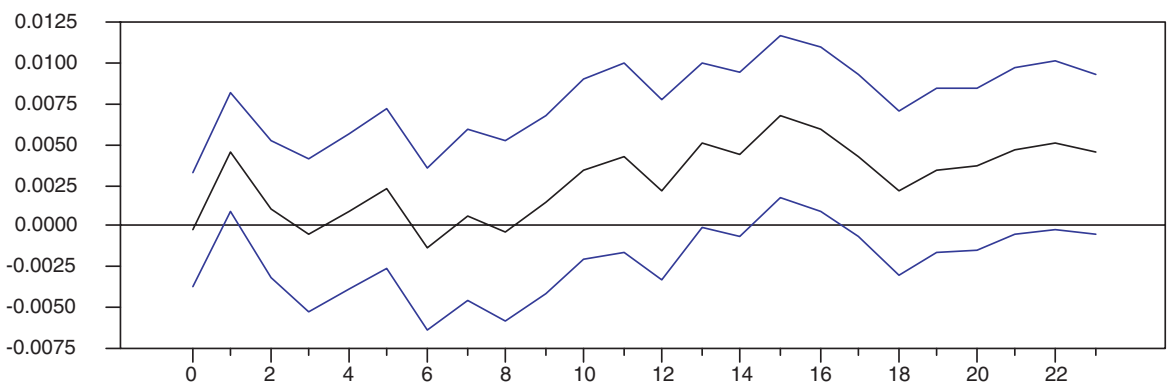

iii. Response of rerspo to $_{t}$ parity

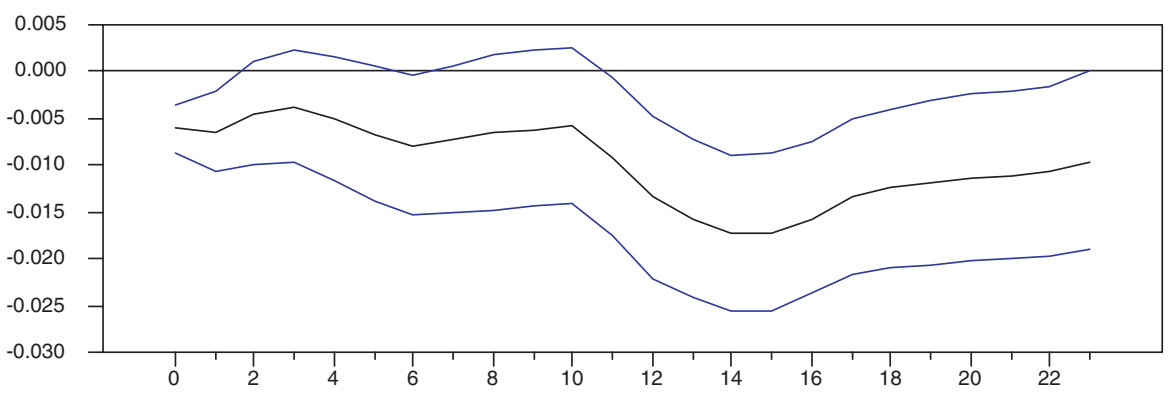

iv. Response of $t r b_{t}$ to parity

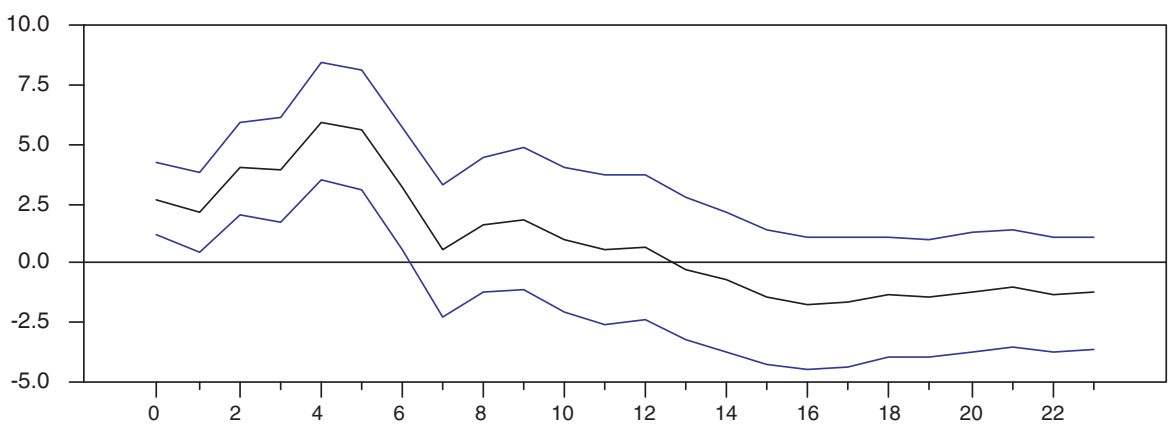

Fig. 4. Impulse response functions (SPO definition used as real exchange rate)

exchange rate with the SPO definition is also appreciation, but this effect is not significant between the third and tenth months. Lastly, trade balance improves for six months in a statistically significant fashion. Comparing Figs 3 and 4, i.e. comparing the effects of using different definitions of the real exchange rate, the attitudes of the effect are similar but the latter one has wider confidence bands. 
To summarize, a positive shock to USD-Euro parity affects relative income in the long run; however, it results in appreciation in real exchange rate and an increase in the trade balance. As a robustness test, the order of variables in the second block is changed so that the trade balance is placed before the real exchange rate and the analysis is repeated. The impulse response functions are reported in the Appendix (Figs A1 and A2). The results are robust.

Finally, the estimates could be capturing the effects of terms of trade rather than the effects of USD-Euro parity. To account for this, the effects of parity were tested for after including the terms of trade variable in the specification. First, the terms of trade enters into the analysis as an exogenous variable. The lag of the terms of trade were included in A3. Second, both the current value and its first lag are given in A4. The results do not change even when the terms of trade is controlled as an exogenous variable. Third, in A5, the terms of trade were included in the model as an endogenous variable. To test whether parity is a proxy for the terms of trade effect, the terms of trade as the first variable were put in the second block. The analysis indicates that the terms of trade improve with a parity shock. On the other hand, the real exchange rate appreciates and trade balance improves as in the case without the terms of trade. Lastly, in A6, the terms of trade instead of parity were put and the effects of a change in terms of trade on the other variables analysed. This analysis suggest that an improvement in the terms of trade results in a depreciation in the real exchange rate and does not affect the relative output nor the trade balance.

\section{Conclusion}

The purpose of this paper is to analyse the effects of change in the parity of the world's major currencies on small open economies. To be specific, this paper assesses how the value of the Euro in terms of the USD affects economic performance in Turkey. Turkey imports goods mostly in USD and exports in Euros. The empirical evidence provided in this paper suggests that the appreciation in the Euro against the USD increases output in the long run, appreciates the local currency and improves the trade balance.

\section{Acknowledgements}

The views presented here are those of the authors; they do not necessarily reflect the official position of the State Planning Organization or its staff.
Both authors would like to thank the members of the Pazar11 discussion group, Anita Akkaş, Bilin Neyapti, Özge Şenay and Taner Yiğit for their helpful comments and suggestions.

\section{References}

Backus, D. K. (1993) Interpreting comovements in the trade balance and the terms of trade, Journal of International Economics, 34, 375-87.

Backus, D. K., Kehoe, P. J. and Kydland, F. E. (1994) Dynamics of the trade balance and the terms of trade: the J-curve?, American Economic Review, 84, 84-103.

Berument, H. and Pasaogullari, M. (2003) Effects of the real exchange rate on output and inflation: evidence from Turkey, Developing Economies, 41(4), 401-35.

Cashin, P. and McDermott, C. J. (1998) Terms of trade and the current account, IMF Working Paper 177.

Cushman, D. and Zha, T. (1997) Modifying monetary policy in a small open economy under flexible exchange rates, Journal of Monetary Economics, 39(3), 433-48.

Fisher, L. A. and Huh, H.-S. (2002) Real exchange rates, trade balances and nominal shocks: evidence for the G-7, Journal of International Money and Finance, 21(4), 497-518.

Gordon, D. B. and Leeper, E. M. (1994) The dynamic impacts of monetary policy: an exercise in tentative identification, Journal of Political Economy, 102, $1128-47$

Deardorff, A. V. and Stern, R. M. (1978) The terms of trade effect on expenditure, Journal of International Economics, 8, 409-14.

Harberger, A. C. (1950) Currency appreciation, income and the balance of trade, Journal of Political Economy, 58, 47-60.

Kamin, S. B. and Rogers, J. H. (2000) Output and the real exchange rate in developing countries: an application to Mexico, Journal of Development Economics, 61, 85-109.

Kent, C. (1997) The response of the current account to terms of trade shocks: a panel data study, Research Discussion Paper 9705

Laursen, S. and Metzler, L. A. (1959) Flexible exchange rates and the theory of employment, Review of Economics and Statistics, 32, 281-99.

Mendoza, E. G. (1992) The effects of macroeconomic shocks in a basic equilibrium framework, IMF Staff Papers, 39(4), 855-89.

Mendoza, E. G. (1995) The terms of trade, the real exchange rate and economic fluctuations, International Economic Review, 36(1), 101-37.

Obstfeld, M. (1982) Aggregate spending and the terms of trade: is there a Laursen-Metzler effect?, Quarterly Journal of Economics, 97, 251-70.

Ostry, J. D. and Reinhart, C. M. (1992) Private savings and terms of trade, IMF Staff Papers, 32, 541-73.

Otto, G. (2003) Terms of trade shocks and the balance of trade: there is a Harberger-Laursen-Meltzer effect, Journal of International Money and Finance, 22, 155-84.

Sachs, J. D. (1981) The current account and macroeconomic adjustment in the 1970s, Brookings Papers on Economic Activity, 5(1), 201-68. 
Sims, C. A. (1972) Money, income and causality, American Economic Review, 62, 540-52.

Sims, C. A. (1986) Are forecasting models usable for policy analysis?, Quarterly Review of the Federal Reserve Bank of Minneapolis, 10, 2-16.

Sims, C. A., Stock, J. H. and Watson M. W. (1990) Inference in linear time series models with some unit roots, Econometrica, 58, 113-47.
Sims, C. A., and Zha, T. (1998) Error bands for impulse responses, Econometrica, 67(5), 1113-56.

Spatafora, N. (2003) How concerned should developing countries be about G-3 exchange rate volatility, World Economic Outlook, Chapter II, 92-111.

Zha, T. (1999) Block recursion and structural vector autoregressions, Journal of Econometrics, 90, $291-316$

\section{Appendix A1: Impulse Response Functions in Different Ordering}

i. Response of parity to parity $y_{t}$

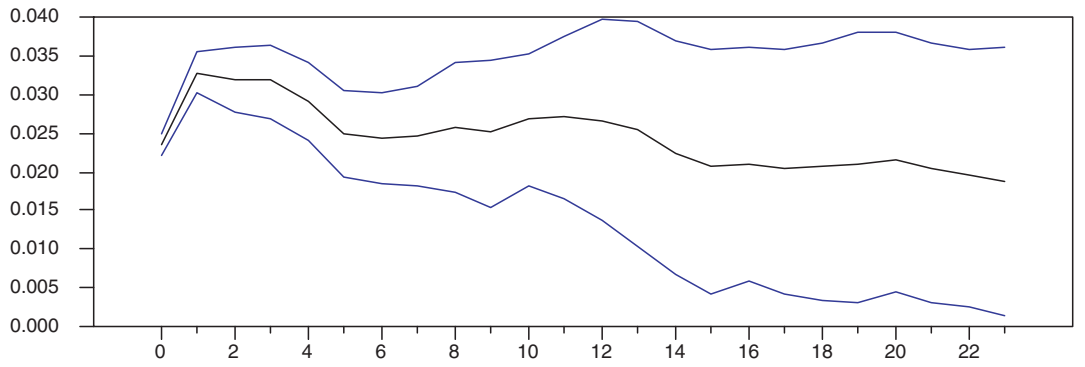

ii. Response of rely to $_{\text {parity }}$

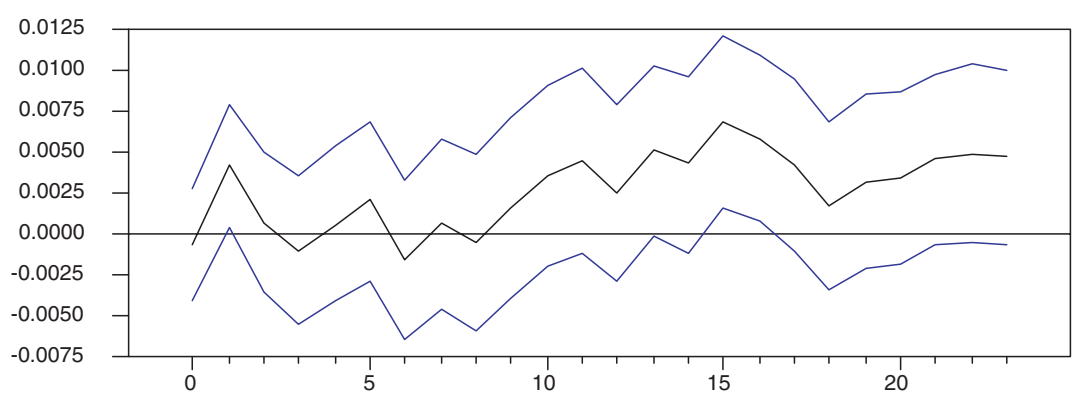

iii. Response of $t r b_{t}$ to parity $_{t}$

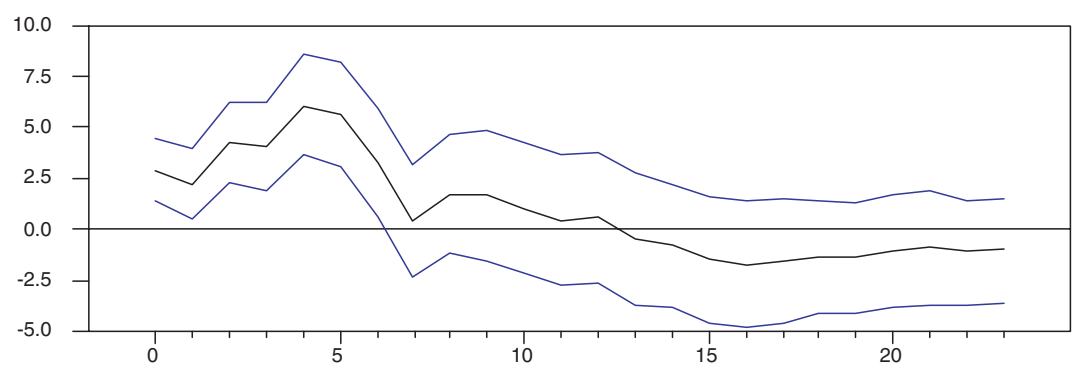

iv. Response of rer $_{t}$ to parity

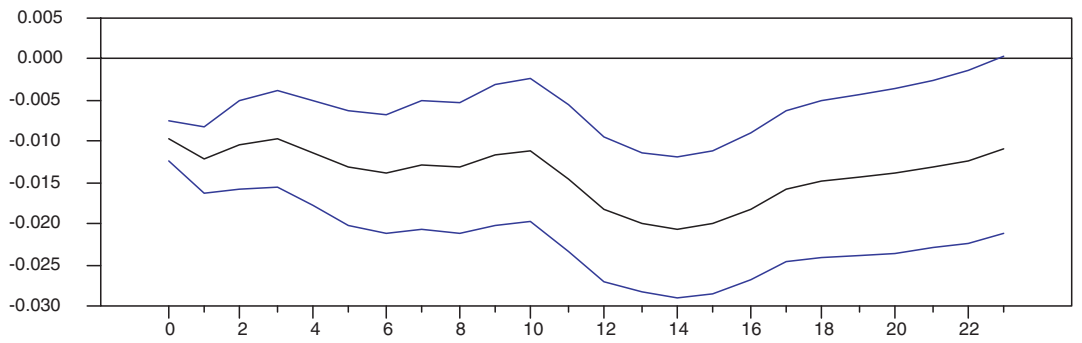


Appendix A2: Impulse Response Functions (SPO Definition Used as Real Exchange Rate) with Different Ordering

i. Response of parity to parity

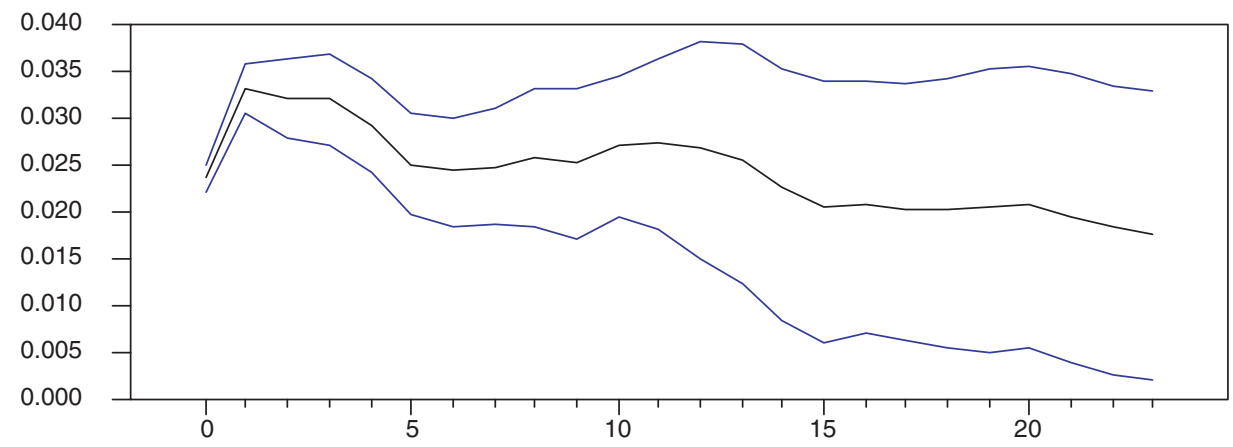

ii. Response of rely to $_{t}$ arity $y_{t}$

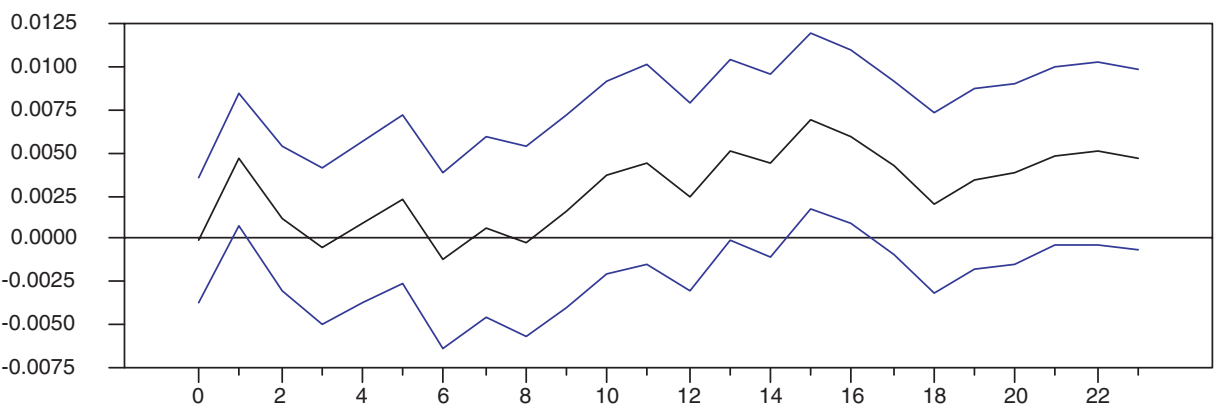

iii. Response of trb $_{t}$ to parity $_{t}$

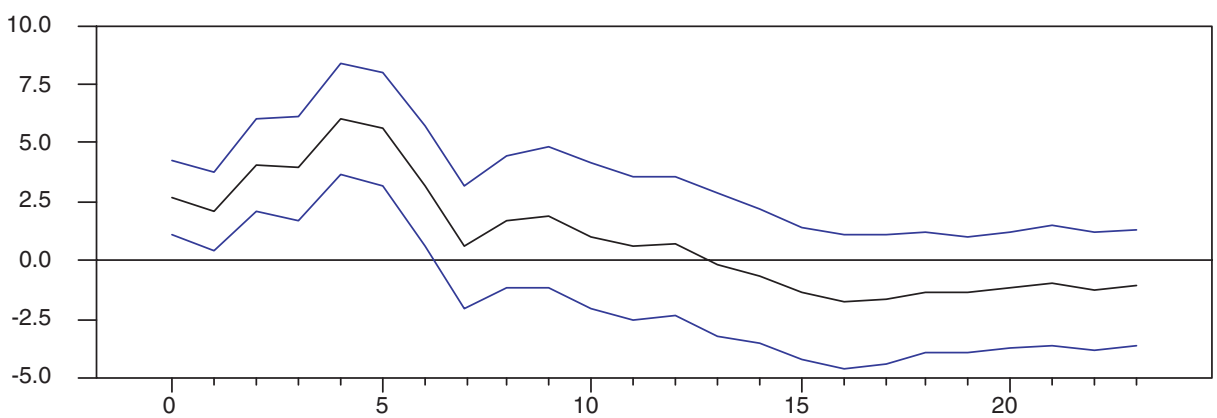

iv. Response of rerspo to parity

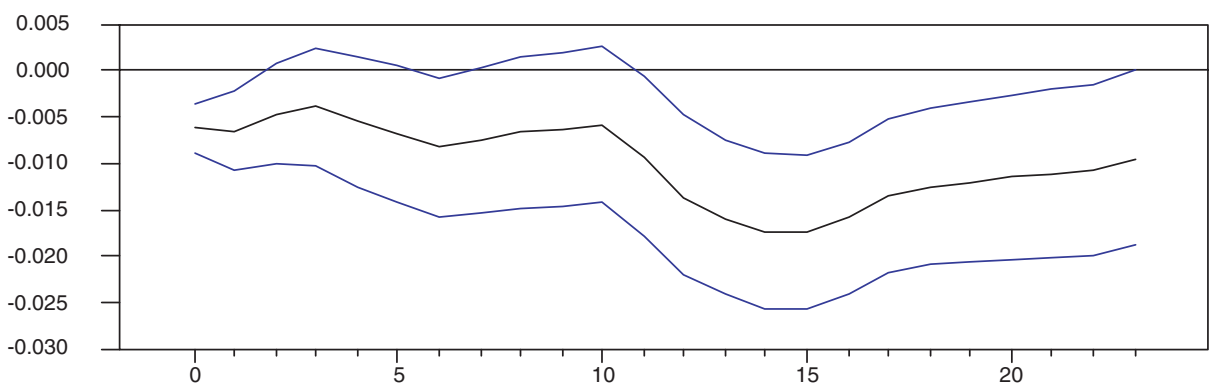


Appendix A3: Impulse Response Functions when Terms of Trade (1st Lag) is Included as an Exogenous Variable

i. Response of parity $_{t}$ to parity $_{t}$

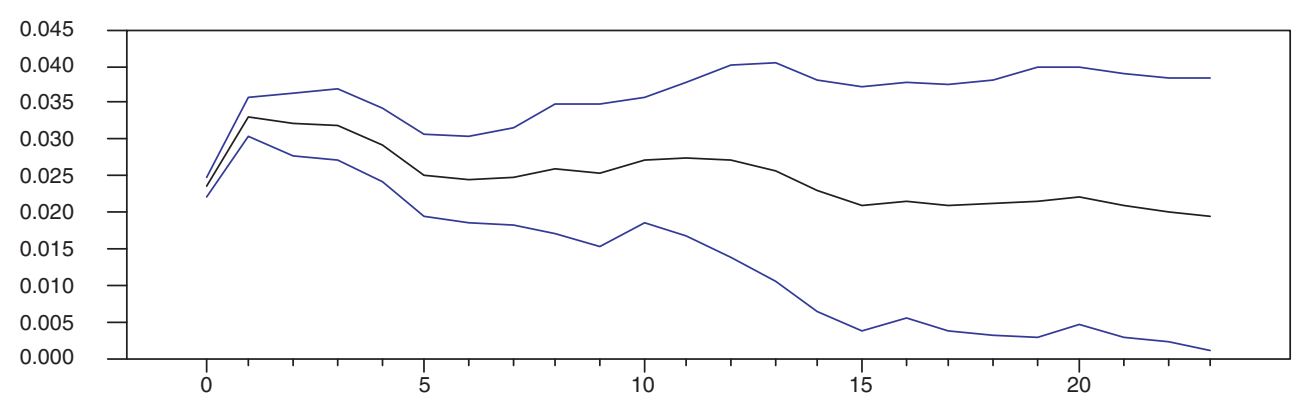

ii. Response of rely to parity

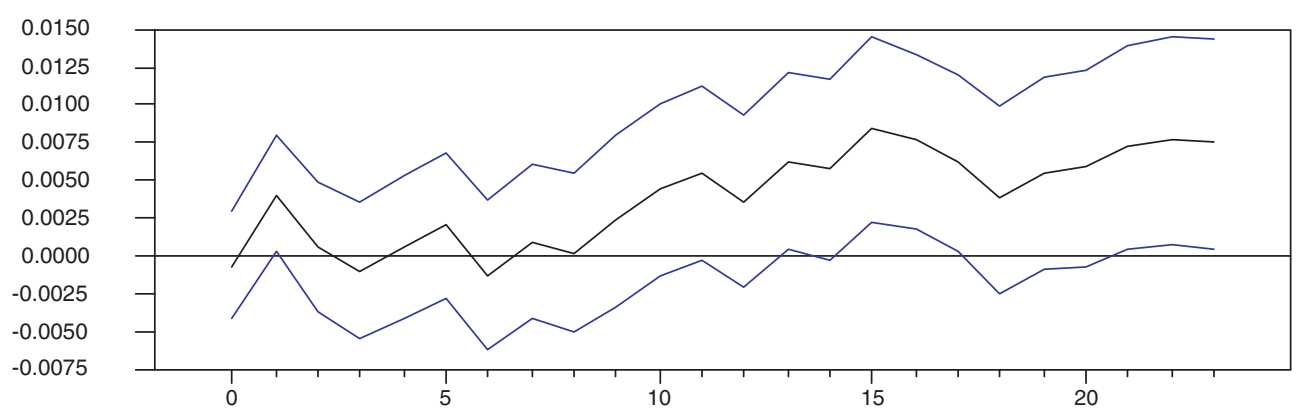

iii. Response of rer $_{t}$ to parity $t_{t}$

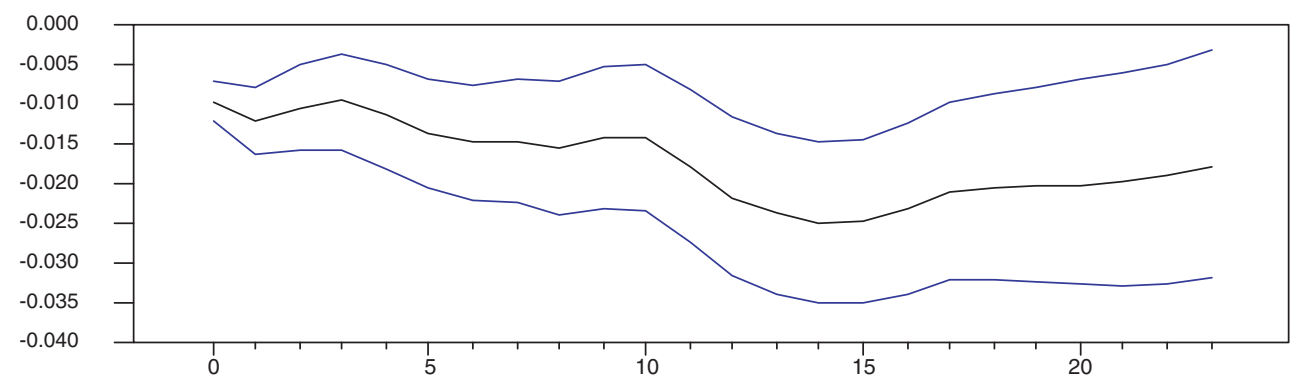

iv. Response of $t r b_{t}$ to parity

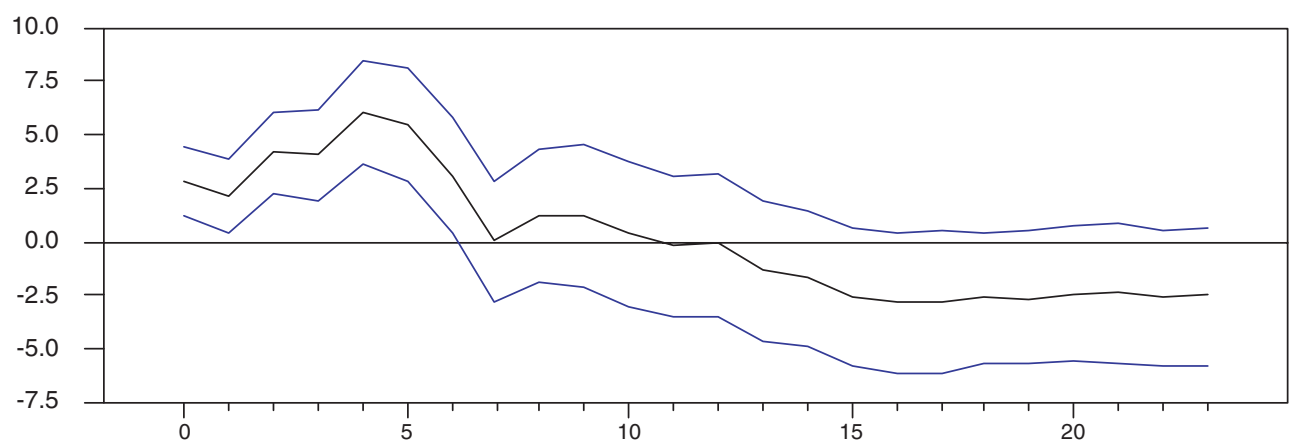


Appendix A4: Impulse Response Functions when Terms of Trade (Current and 1st Lag) is Included as an Exogenous Variable

i. Response of parity $_{t}$ to parity $_{t}$

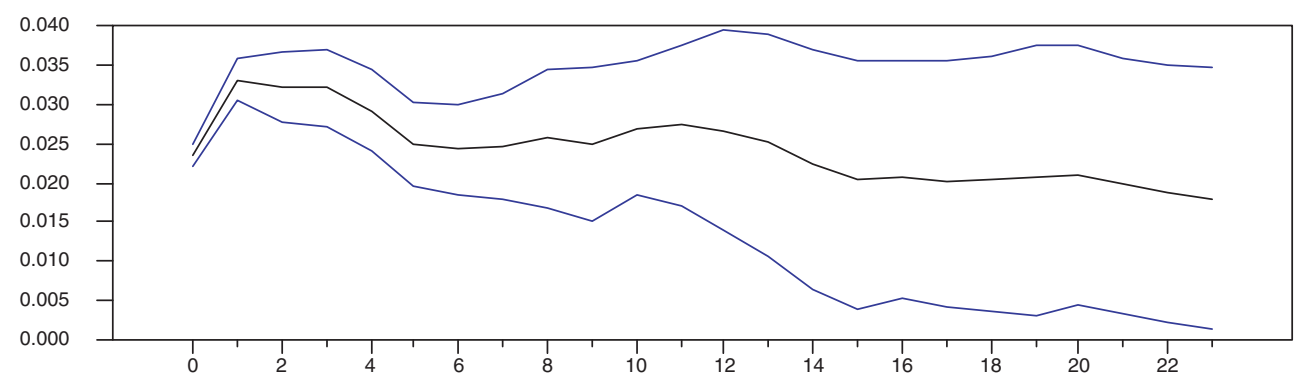

ii. Response of rely to $_{t}$ arity

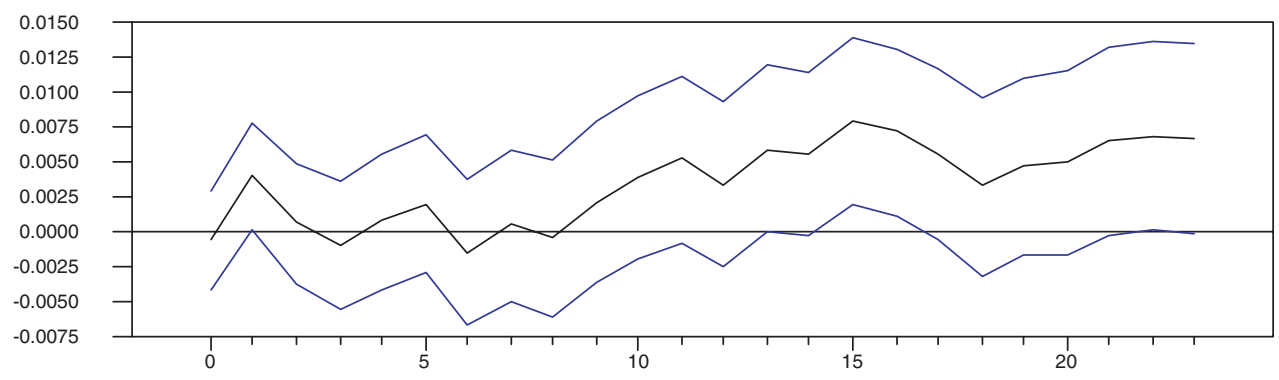

iii. Response of rer $_{t}$ to parity $_{t}$

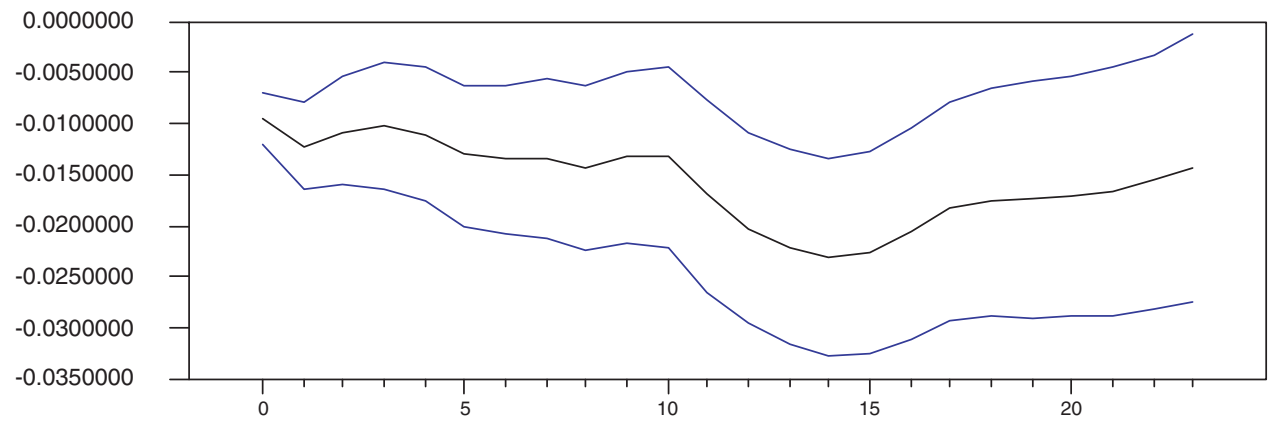

iv. Response of $t r b$ to parity

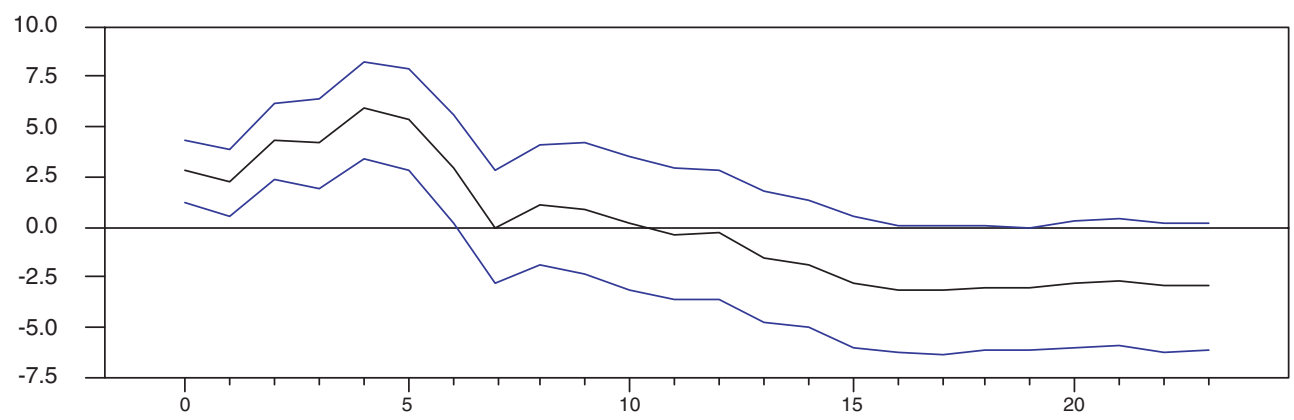


Appendix A5: Impulse Response Functions Including Terms of Trade

i. Response of parity $_{t}$ to parity $_{t}$

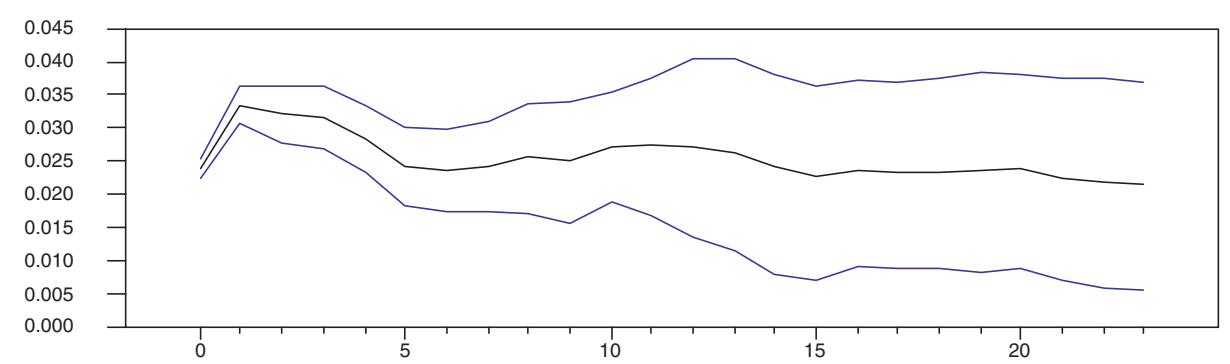

ii. Response of ltot $_{t}$ to parity

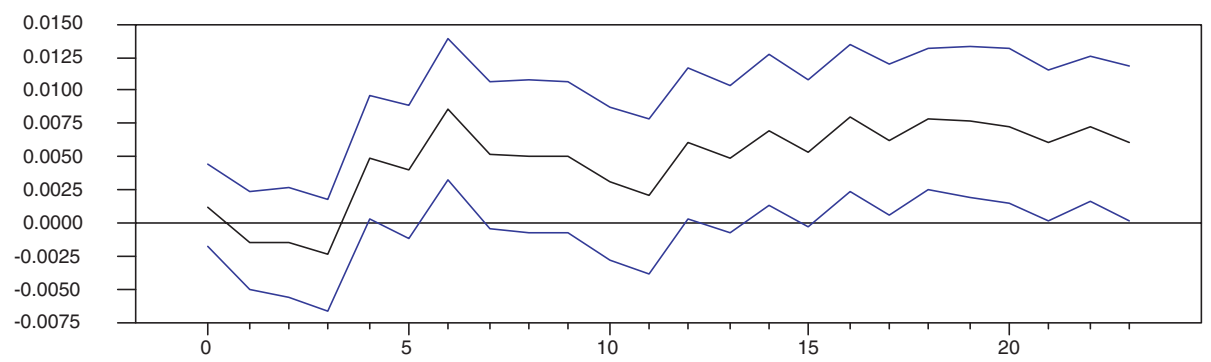

iii. Response of rely to $_{t}$ parity $t_{t}$

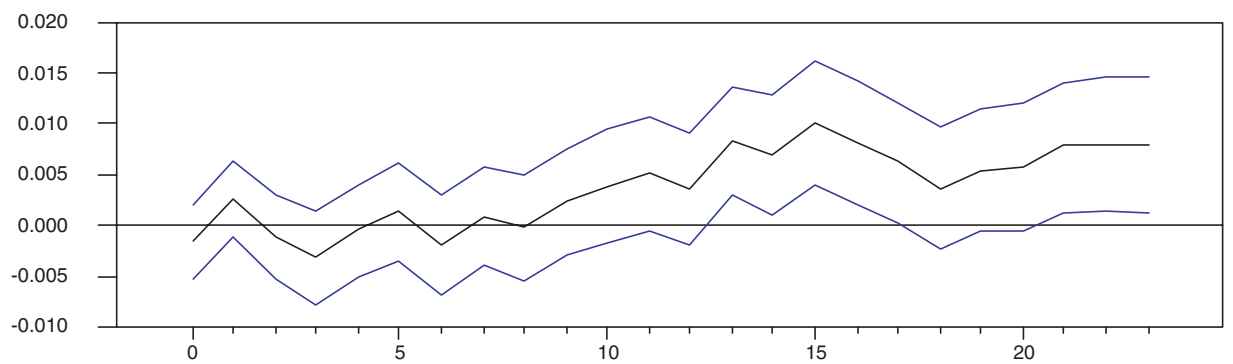

iv. Response of rer $_{t}$ to parity

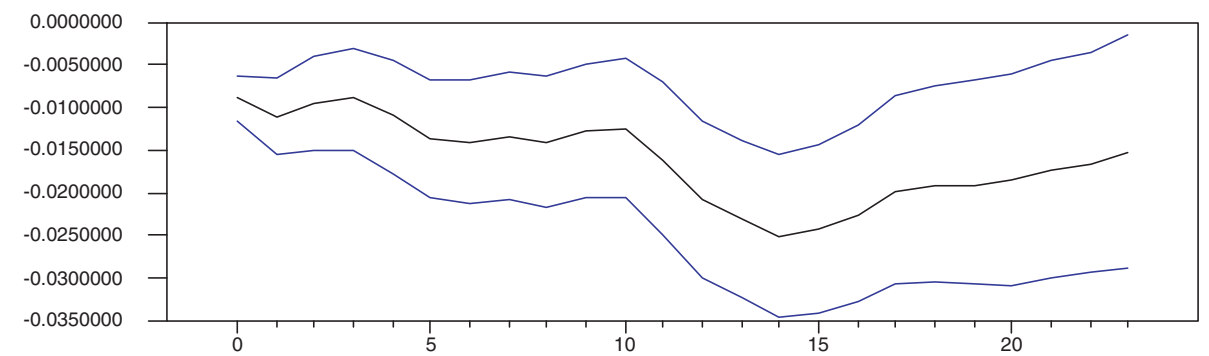

v. Response of $t r b_{t}$ to parity

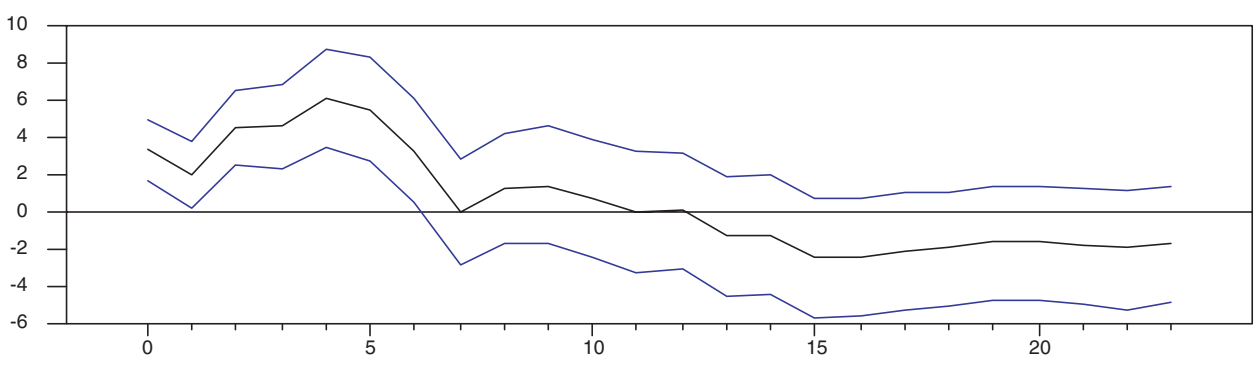


Appendix A6: Impulse Response Functions for Robustness (Parity is Excluded)

i. Response of ltot $_{t}$ to ltot $_{t}$

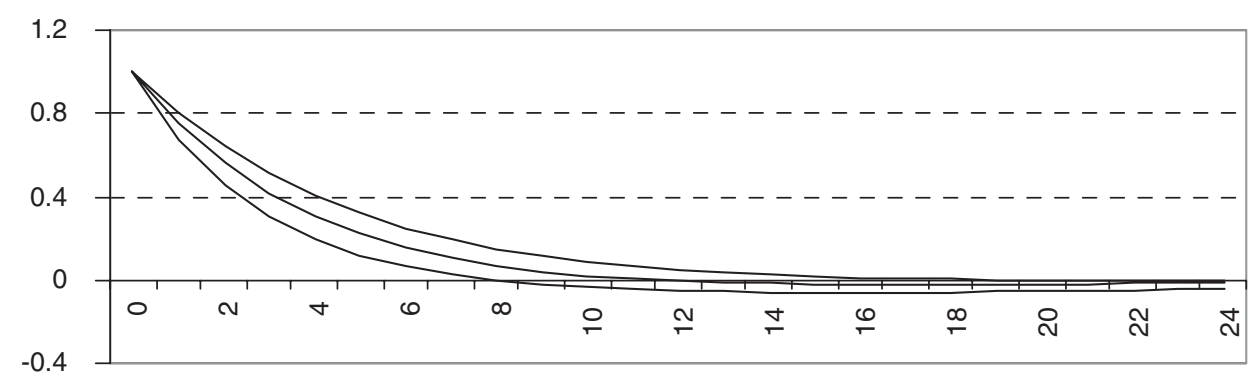

ii. Response of rely to $_{t}$ tot $_{t}$

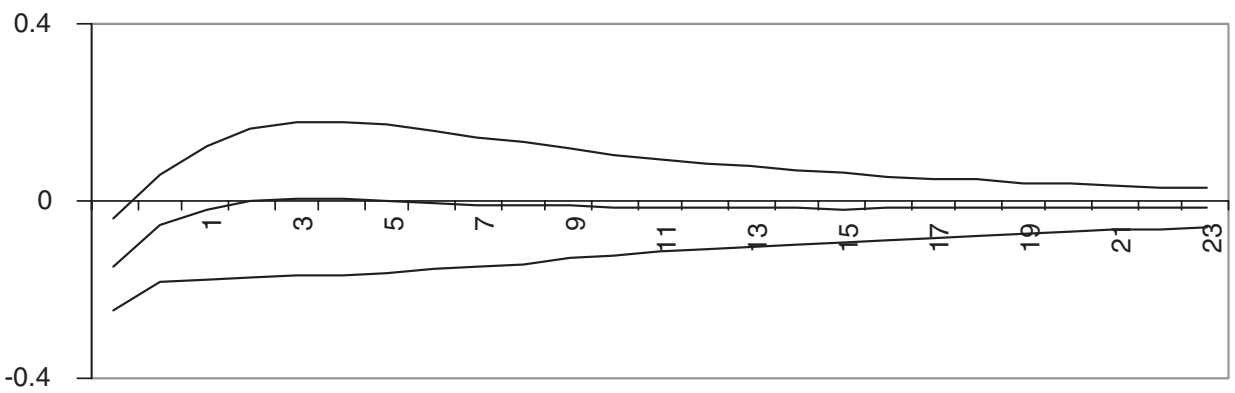

iii. Response of rer $_{t}$ to ltot $_{t}$

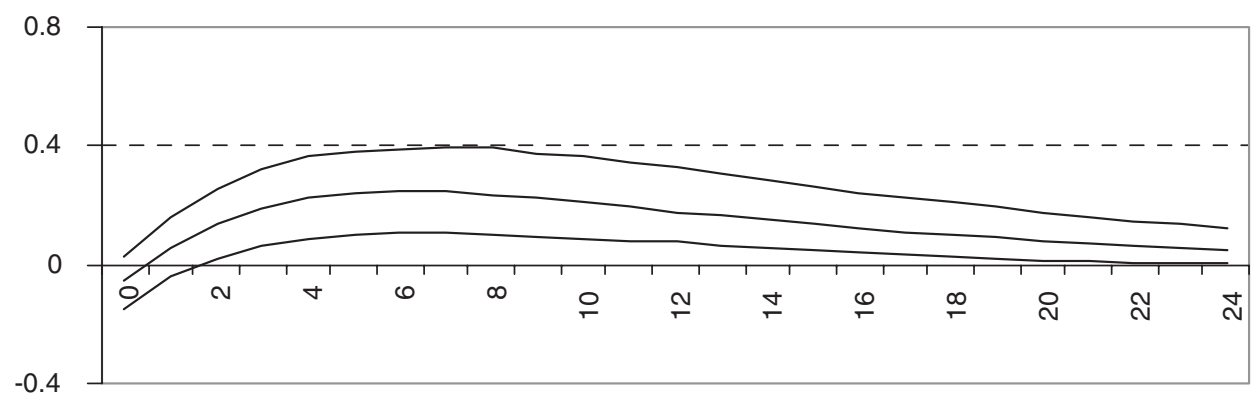

iv. Response of $t r b_{t}$ to ltot $_{t}$

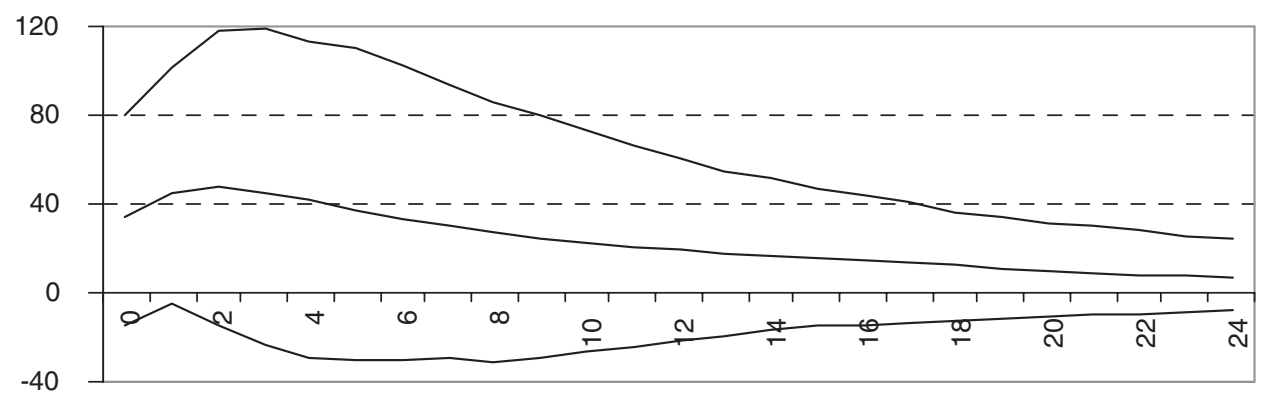

